\title{
The trace fossil Neonereites multiserialis Pickerill and Harland, 1988 from the Devonian Wapske Formation, northwest New Brunswick
}

\author{
Ron K. Pickerill \\ Department of Geology, University of New Brunswick, Fredericton, New Brunswick E3B 5A3, Canada
}

Date Received May 4, 1991

Date Accepted August 29, 1991

\begin{abstract}
The trace fossil Neonereites multiserialis Pickerill and Harland is recorded and described from the Lower Devonian Wapske Formation of northwest New Brunswick. Preserved typically in positive hyporelief on sandstone soles, the ichnospecies can potentially be confused with morphologically similar ichnotaxa, particularly Granularia Pomel, Ophiomorpha Lundgren, Ardelia Chamberlain and Baer and Edaphichnium Bown and Kraus, and is best differentiated by undertaking, whenever possible, vertical transverse and longitudinal sectioning of the structures. The records and included proposed synonymy suggest that Neonereites multiserialis is Silurian (Wenlock) to Tertiary (Eocene) in age and is indicative of deep-water flysch environments.
\end{abstract}

La Formation de Wapske (Dévonien inférieur, nord-ouest du Nouveau-Brunswick) a livré l'ichnite Neonereites multiserialis Pickerill et Harland, dont on fournit ici une description. Il est parfois délicat de distinguer cette ichnoespèce, typiquement conservée en demi-relief convexe à la base des bancs de grès, de formes voisines (notamment Granularia Pomel, Ophiomorpha Lundgren, Ardelia Chamberlain et Baer, Edaphichnium Bown et Kraus). L'étude du matériel par coupes longitudinales et transversales constitue, le cas échéant, la meilleure approche afin de trancher la question. La documentation fossile et la synonymie que l'on propose suggèrent que Neonereites multiserialis s'échelonne du Silurien (Wenlock) au Tertiaire (Éocène) et fait foi de milieux d'eau profonde, sièges d'une sédimentation à caractère flyschoïde.

[Traduit par le journal]

INTRODUCTION

The trace fossil ichnogenus Neonereites Seilacher, 1960 characteristically comprises straight, sinuous to irregularly curving, loose or interconnected chains of variably impressed dimples (when preserved on upper bedding plane surfaces in negative epirelief) or pustules, pills or knobs (when preserved on lower bedding plane surfaces in positive hyporelief - their more typical style of preservation) (Seilacher, 1960; Fillion and Pickerill, 1990a). To date, four ichnospecies have been described, namely Neonereites uniserialis Seilacher, 1960, N. biserialis Seilacher, 1960, N. multiserialis Pickerill and Harland, 1988 and $N$. renarius Fedonkin, 1980. As the etymology suggests, the first three are characterized, respectively, by single, double and multiple rows of dimples or, particularly, pustules, pills or knobs. Neonereites renarius is similar to $N$. uniserialis in that it comprises rows of uniserial pustules but is differentiated on the basis of its reniform-as distinct from hemispherical-shaped protruberances. Neonereites uniserialis and $N$. biserialis have each been commonly reported in the geological literature and range in age from late Proterozoic to Eocene (Häntzschel, 1975; Crimes, 1987; Narbonne et al., 1987; Gibson, 1989). Neonereites renarius has, to my knowledge, only been documented from the Vendian of Russia and $N$. multiserialis has, until now, only been formally recorded from a single location from Silurian strata of North Greenland.

Crimes and Crossley (1991) suggested that Neonereites multiserialis could be accommodated within $N$. biserialis, thereby indirectly suggesting that $N$. multiserialis is a subjective junior synonym of $N$. biserialis. However, better preserved examples of $N$. multiserialis recovered from Devonian strata of New Brunswick, demonstrate that the suggestion of Crimes and Crossley (1991) is speculative at best. In describing these Devonian examples, transverse and longitudinal thin sections of the structures have also been utilized in an attempt to better understand their 3-dimensional and internal geometry. Typically such an approach has, historically, been overlooked in the description of Neonereites but, as demonstrated later, is of critical importance in the differentiation of the trace fossil from several other ichnogenera.

The purpose of this contribution is therefore to (1) document and describe in detail $N$. multiserialis from Devonian strata of New Brunswick, thereby (2) reiterating its legitimacy as a distinctive ichnotaxon, and (3) extending its known stratigraphic range from the only previously documented recording from the Silurian of North Greenland to the Tertiary (Eocene). 


\section{Geological Details}

Specimens described here are from three locations within the Lower Devonian (Helderbergian) Wapske Formation of the Tobique Group of the Riley Brook area of northwestern New Brunswick, eastern Canada (Fig. 1). This formation comprises an essentially siliciclastic sedimentary sequence with lesser proportions of felsic and mafic volcanics, that was deposited in a relatively deep marine environment (Pickerill, 1986; Wilson, 1990). Sedimentary facies consist of thinly bedded ( $1-5 \mathrm{~cm}$, rarely $5-10 \mathrm{~cm}$ thick), fine- to mediumgrained, grey, green, brown or orange-brown sandstones interbedded with $1-3 \mathrm{~cm}$ thick shales. Although no detailed sedimentological analysis of this sequence has been undertaken, studies of coeval strata to the southwest (e.g., St. Peter, 1978, 1979; Pickerill, 1986) and northeast (e.g., Wilson, 1990) of the Riley Brook area suggest that the Wapske Formation represents a relatively deep water turbiditic sequence deposited below storm wave base, perhaps on an ancient slope. The thinly-bedded sandstones commonly exhibit partial Bouma sequences, particularly $\mathrm{Tb}, \mathrm{Tb}-\mathrm{c}, \mathrm{Tb}-\mathrm{d}$ and less commonly Ta-b sequences. Interbedded shales are difficult to sample, and internal structures are typically indiscernible.

Within the area depicted in Figure 1, Neonereites multiserialis was collected at three locations. These are: (i) East bank of the Tobique River, ca. $1 \mathrm{~km}$ northeast of the village of Riley Brook; (ii) Roadside section along Frasers Private Road along the Little Tobique River at Nictau; (iii) Roadside section along Route 385 parallel to the Mazarel River, ca. 1 km northeast of the Everett Brook/Mazarel River confluence.

Additional ichnotaxa at these and other locations are still under study but preliminary analysis has revealed the presence of Chondrites von Sternberg, Cochlichnus Hitchcock, cf. Conostichus Lesqueureux, Cosmorhaphe Fuchs, Cruziana d'Orbigny, Helminthopsis Heer, Neonereites uniserialis Seilacher, Neonereites biserialis Seilacher, Palaeophycus Hall, Phycodes Richter, Planolites Nicholson, Protovirgularia McCoy, Skolithos Haldemann, Taenidium Heer and Umfolozia Savage.

\section{Systematic Palichnology}

\section{Ichnogenus Neonereites Seilacher, 1960}

Type ichnospecies Neonereites biserialis Seilacher, 1960 by original designation

\section{Diagnosis}

Straight, irregularly or regularly winding chains of generally loose or interconnected pustules, pods or knobs when preserved in positive relief on lower bedding plane surfaces or corresponding dimples, more rarely pustules, pods or knobs, on upper bedding plane surfaces (modified after Seilacher, 1960; Hakes, 1976; Fillion and Pickerill, 1990a).

\section{Remarks}

Since Seilacher and Meischner (1965) first suggested that the ichnogenus Neonereites perhaps represented but one preservational variant of Nereites MacLeay, 1839 [others possibly including Scalarituba, Weller, 1899 and Phyllodocites Geinitz, 1867-see also Seilacher (1983)] Neonereites has proven to be a continual source of nomenclatural confusion. With exceptionally well-preserved material, Chamberlain (1971) demonstrated that his examples of $\mathrm{Ne}$ onereites represented the convex hyporelief (or basal surface) view of internally complex burrows that possessed lateral lobes characteristic of Nereites and a meniscate median gallery characteristic of Scalarituba (see also Fillion and Pickerill, 1990a). He therefore proposed (Chamberlain, 1971) that Neonereites was a subjective junior synonym of Scalarituba, and expanded the definition of Scalarituba to include a 'Nereites view' in convex hyporelief on lower surfaces and a 'Phyllodocites view' in concave epirelief on upper surfaces. This approach, however, has only been adopted on occasion by authors such as Chaplin (1980), who did not observe the complete 3-dimensional variation of his material, and Seilacher (1983), who described material similar to, but not as ideally preserved as Chamberlain's (1971), as Nereites, though he still retained Scalarituba and Neonereites (see also D'Alessandro and Bromley, 1987). Indeed, most authors (e.g., Tanaka, 1971; Fedonkin, 1977, 1985; Crimes et al., 1981; Benton, 1982; Crimes and Germs, 1982; Palij et al., 1983; Pacześna, 1986; McCann and Pickerill, 1988; Powichrowski, 1989; Gibson, 1989; Narbonne and Aitken, 1990; Crimes and Crossley, 1991) have retained Neonereites and its ichnospecies as distinctive ichnotaxa. In all probability this more universal concensus reflects one or more of the following:

(i) Preservational variants such as those described by Chamberlain (1971) and Seilacher (1983) are apparently extremely rare in the geological record.

(ii) These preservational variants are all described as having a regular or irregular biserial arrangement of pustules (characteristic of $N$. biserialis). Thus, all additional ichnospecies of Neonereites cannot be accommodated within either Nereites or Scalarituba.

(iii) The most common mode of preservation of Neonereites is in convex hyporelief. Because of sampling or preservational problems, it is typically difficult to ascertain the complete 3-dimensional form of the structures. In such cases assignment to Scalarituba or Nereites could be potentially misleading and even erroneous. This was demonstrated by Pickerill (1981), who vertically sectioned examples of $N$. uniserialis and $N$. biserialis and was unable to discern any Nereites-like or Scalaritubalike features, and by Benton (1982), who described $N$. uniserialis occurring in positive epirelief on upper surfaces and lacking any associated structures.

(iv) As noted by Fillion and Pickerill (1990b), information in palaeontological studies must be unambiguous, accurate 


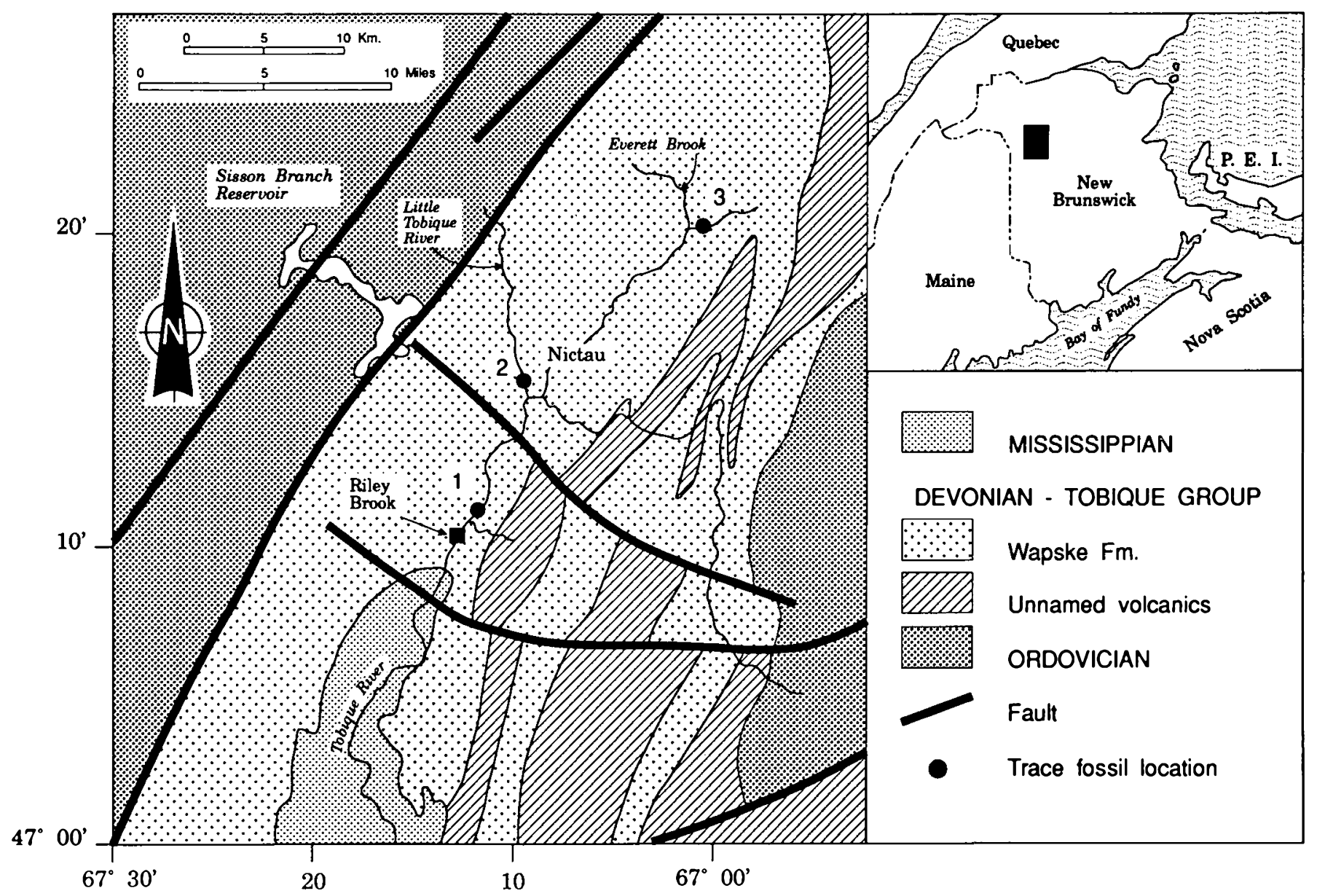

Fig. 1. Simplified geological map of the Riley Brook area of northwestern New Brunswick. Neonereites multiserialis described herein was collected from locations $1-3$, details of which are given in the text.

and easily retrievable, otherwise the communicative function of taxonomy is greatly hampered, particularly by changes at the ichnogeneric level at which most bibliographic surveys are undertaken. Inclusion of $\mathrm{Ne}$ onereites within Nereites or Scalarituba would result in such ambiguities.

Therefore, following most authors I consider Neonereites to be a useful and valid ichnotaxon that should be retained. In ichnology it is not unusual to find combinations and intergradations of several ichnotaxa (see Bromley and Frey, 1974; Pickerill et al., 1984), and in such cases most authors describe the variations accordingly. The nomenclature and concepts of Nereites, Scalarituba and Neonereites as separate and distinctive ichnogenera are so deeply implanted in palaeontological literature that their (rare) occurrence as separate parts of a single burrow system does not require that these forms represent a single ichnotaxon. A similar decision was made by Bromley and Frey (1974) to retain the ichnogenera Gyrolithes de Sapporta, 1884, Thalassinoides Ehrenberg, 1944 and Ophiomorpha Lundgren, 1891, which can similarly exhibit complex integradations with each other, but which Bromley and Frey (1974) considered best retained as discrete ichnotaxa. Thus, if specimens similar to those described by
Chamberlain (1971) and Seilacher (1983) are discovered, nomenclatural assignment should be made with respect to the dominant morphological component. For example, in Seilacher (1983), the two specimens designated as Nereites spp. (fig. 13) should more appropriately be assigned to Nereites (fig. 13a) and Neonereites biserialis (fig. 13b).

As reviewed in Fillion and Pickerill (1990a), Neonereites is a facies-crossing ichnotaxon representing either the endogene burrow, or the trail of a benthic organism, most likely an annelid. It ranges in age from Late Proterozoic to Eocene.

\section{Neonereites multiserialis Pickerill and Harland, 1988} (Fig. 2, 1-5)

1971 Scalarituba missouriensis, sensu Chamberlain, pl. 31, fig. 2 (not paginated).

1980 Scalarituba (Neonereites-view), sensu Chaplin, p. 60, fig. 2 .

1984 Neonereites, Ekdale, Bromley and Pemberton, p. 239, fig. 18-5.

1986 ? Ophiomorphacf. nodosa, sensu Yang, Song and Liang, pl. I, fig. 6 (not paginated). 
1988 Neonereites multiserialis, Pickerill and Harland, p. 127 , figs. 5a,b.

1991 Neonereites multiserialis, Pickerill and Donovan, p. 21, fig. $2 b$.

\section{Diagnosis}

Neonereites composed of more than two rows of pustules or pods in positive hyporelief or dimples in negative epirelief (after Pickerill and Harland, 1988).

\section{Description}

All specimens are preserved on $1-3 \mathrm{~cm}$ thick, orangebrown, parallel laminated, fine-grained sandstone soles in positive hyporelief. They comprise horizontal, unbranched, longitudinally curved to irregularly sinuous chains of interconnected pustules or pods, individual chains being up to 15 $\mathrm{cm}$ in length, but typically less as most specimens are incomplete, being preserved on slabs with a relatively small total surface area. Single pustules are smooth and unornamented, variably impressed ( $<0.1$ to $4 \mathrm{~mm}$ ), variable in size (maximum diameter $4 \mathrm{~mm}$, typically 1 to $2 \mathrm{~mm}$ ) and spheroidal to ellipsoidal. Individual pustules may be discrete or composite in the sense that they comprise subtle amalgamations of up to an observed maximum of six mutually overlapping and smaller-scaled protruberances. Overall width of individual specimens is variable (e.g., Fig. 2.2), up to a maximum of 2 $\mathrm{cm}$, and the number of pustules in cross-section varies from 4 to 7 .

Vertical transverse and longitudinal sections of seven specimens indicate that the pustules are hemispheres and represent the basal surface expression of slightly compressed, broadly reniform-shaped burrows. Of these, five specimens possessed a massive and an apparently structureless fill of slightly different composition to the host rock. Vertical transverse sections of a sixth specimen (NBMG 8375) suggest the presence of a central circular burrow (Fig. 2.5) and indistinct laminae external to the central burrow and parallel to the margins of the entire structure (Fig. 2.3). A longitudinal section of the seventh specimen (Fig. 2.4) exhibits a generally massive lower burrow fill and an upper portion exhibiting relatively closely spaced, albeit poorly-preserved and not pervasively developed, crescentic menisci. Horizontal sections of several examples were constructed but failed to reveal details of the laminae or menisci as observed in vertical section.

\section{Material}

Twenty specimens from talus material at locations 1-3 of Figure 1. Two figured specimens and three thin sections reposited in the Division of Natural Sciences, New Brunswick Museum, Saint John, New Brunswick [NBMG 8375/1/ $2 / 3$ ( 1 is the actual specimen, now incomplete, 2 and 3 are thin sections from the specimen), 8376 (not sectioned) and 8377 (thin section only; specimen destroyed during sectioning)].
Additional material housed in the Department of Geology, University of New Brunswick.

\section{Remarks}

As noted previously, Neonereites includes four ichnospecies, namely $N$. uniserialis, $N$. biserialis, $N$. multiserialis and $N$. renarius. The multiserial arrangement of pustules in the New Brunswick specimens characterizes them as $N$. multiserialis. Vertical sectioning of seven specimens clearly revealed that, at least in these examples, $N$. multiserialis represents the basal surface expression of intergenic (sensu Chamberlain, 1971) burrows. Of the seven sectioned examples only two exhibited internal structures similar to those described by Seilacher and Meischner (1965), Chamberlain $(1971,1978)$ and Seilacher (1983) and, as previously discussed, assigned by these authors to either Nereites or Scalarituba. The remaining five examples contained an apparently structureless fill, thereby obviously not conforming to the definitions of Nereites or Scalarituba, but still possessed the multiserial pustules characteristic of $N$. multiserialis.

The included synonymy (see above) incorporates personally examined material previously assigned to Neonereites multiserialis (Pickerill and Harland, 1988; Pickerill and Donovan, 1991) and material considered as $N$. multiserialis. Thus, the multiserial convex hyporelief pustules figured by Chamberlain (1971), Chaplin (1980) and Ekdale et al. (1984) are regarded as conspecific. Ophiomorpha cf. nodosa figured by Yang et al. (1986) is identified by them as such on the presence of a single compressed burrow preserved in convex hyporelief. As this ichnogenus is more typically preserved as a vertical structure and knowledge of its 3-dimensional morphology was not determined, it is questionably included in the synonymy. Inclusion within Neonereites multiserialis is further suggested by its association with $N$. uniserialis and its co-occurrence with typical deep water ichnotaxa, as $N$. multiserialis, at least to date, has only been reported from flysch sequences.

When viewed as positive hyporeliefs small or isolated segments of Neonereites multiserialis could conceivably be confused with several additional ichnotaxa, namely Granularia Pomel, 1849, Ophiomorpha Lundgren, 1891, Ardelia Chamberlain and Baer, 1973 and Edaphichnium Bown and Kraus, 1983. These ichnotaxa are all characterized by burrows with walls that are distinctly pelleted to give an external surface appearance superficially similar to that of $N$. multiserialis, and each can potentially be preserved as positive hyporeliefs. The following outlines the essential characteristics of these ichnotaxa in order to establish important differences with respect to $N$. multiserialis.

As discussed by Crimes et al. (1981), the diagnosis of Granularia is unclear and a monographic treatment of the ichnogenus and related forms appears necessary. These authors utilized Granularia for twig-like, commonly branched, burrows with linings of small sand or mud pellets similar to an example figured in the Treatise on Invertebrate Paleontology by Hăntzschel (1975, fig. 40, 3b, p. W66). The presence 

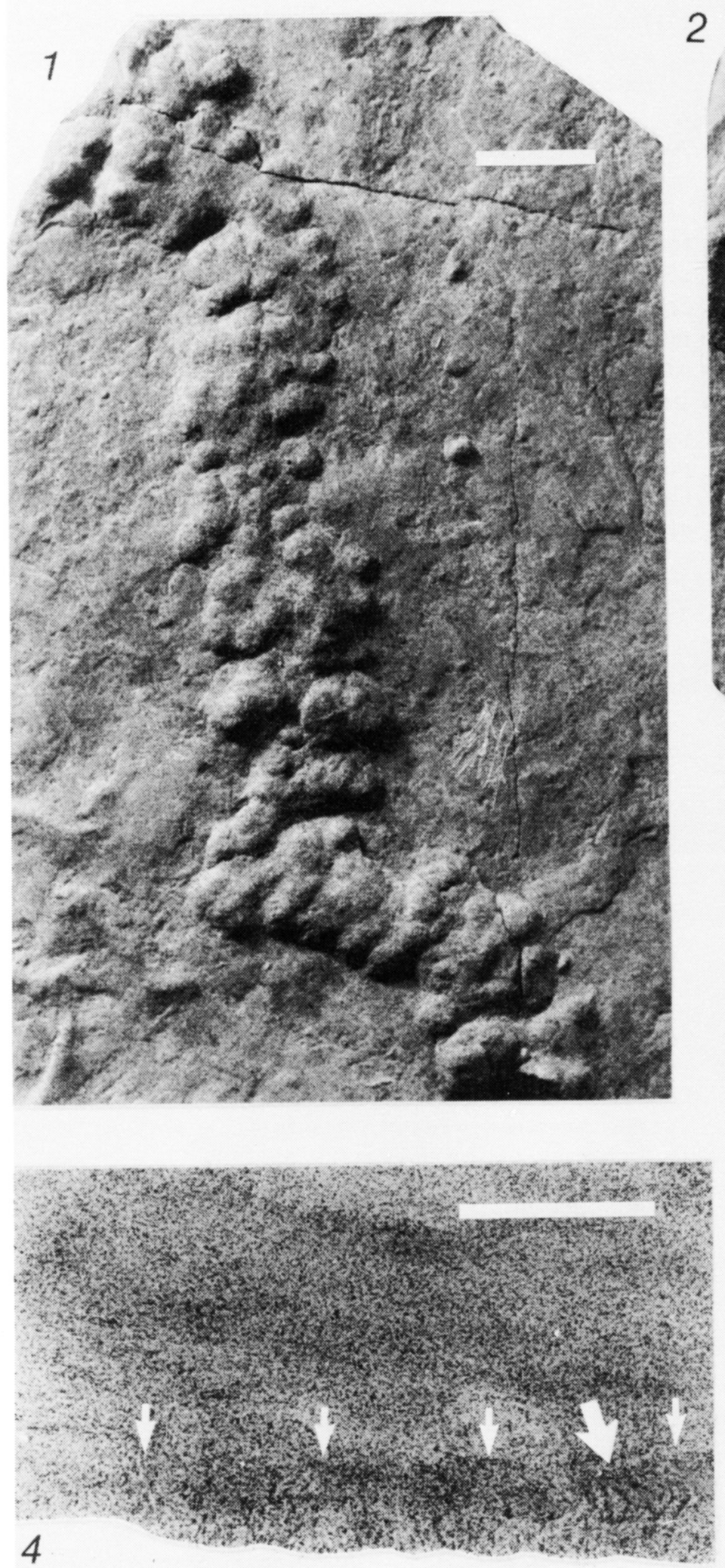

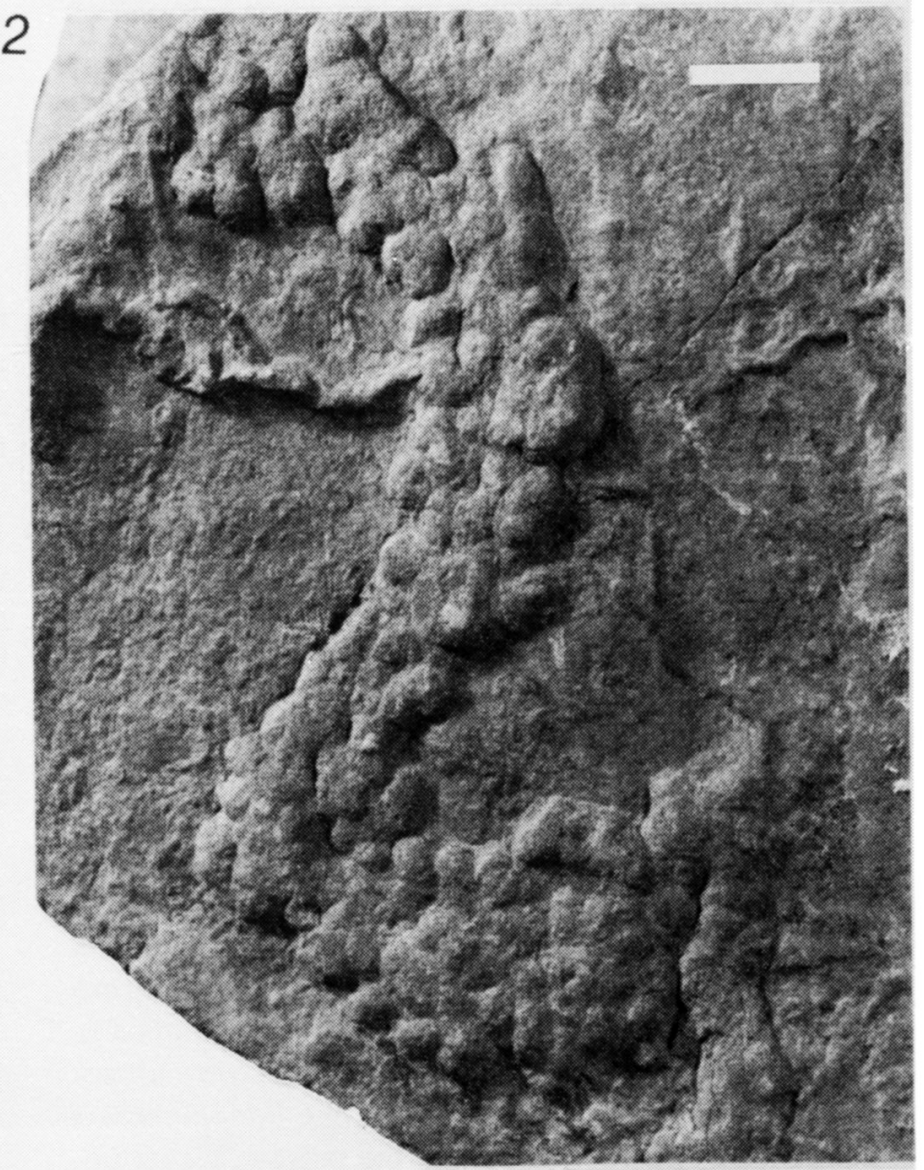

3
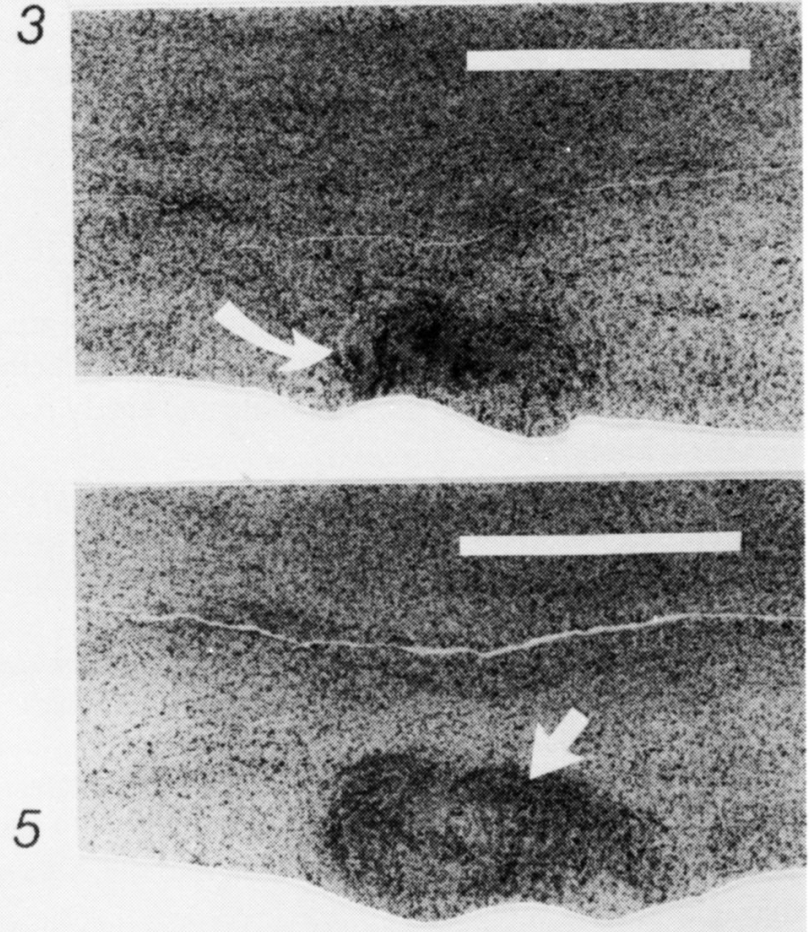

Fig. 2. (1) Neonereites multiserialis preserved in positive relief on a sandstone sole, NBMG 8375/1. (2) N. multiserialis preserved in positive relief on a sandstone sole, illustrating lateral variability of pustule development, NBMG 8376. (3) Vertical transverse thin section of NBMG 8375/2 exhibiting laminae paralleling the outer margin of the burrow wall (arrowed). (4) Vertical longitudinal thin section of NBMG 8377 illustrating massive lower fill and sparse development of crescentic menisci (large arrow); small arrows denote upper margin of burrow. (5) Vertical transverse section of NBMG 8375/3 exhibiting a more or less centrally located circular burrow (arrowed) Bar scales on all figures $=1 \mathrm{~cm}$. 
of a distinctive pellet lining prompted Frey et al. (1978) to suggest that Granularia may well be a synonym of Ophiomorpha. Indeed, Ophiomorpha and its several synonyms (see Frey et al., 1978) are also characterized by burrows that possess distinctive knobbly walls composed of agglutinated pelletoidal sediment. As with Granularia, Ophiomorpha is commonly branched, but in contrast, typically forms an integrated burrow system with regular or irregular horizontal and vertical mazes and boxworks (Frey et al., 1978). Ardelia is very similar morphologically to Ophiomorpha except that it is considerably larger and possesses typically smooth horizontal burrows connected to moderately or highly irregular inclined or vertical mammilated sections (Chamberlain and Baer, 1973). Finally, Edaphichnium is an unbranched, horizontal, cylindrical burrow, commonly filled with fecal pellets that also form the periphery of the burrow, giving the ichnogenus a verrucose or nodose exterior (Bown and Kraus, 1983).

Thus, the essential difference between Neonereites multiserialis and these ichnotaxa is that in examples where $N$. multiserialis comprises the basal expression of horizontal burrows, the pustulose or nodose burrow wall is only developed on the base. Granularia, Ophiomorpha, Edaphichnium and, to a lesser extent, Ardelia, possess burrow walls that are completely pustulose or nodose. Additionally, in contrast to Ardelia, Granularia and Ophiomorpha, Neonereites multiserialis is consistently unbranched, and unlike Edaphichnium does not contain fecal pellets within the burrow. Nevertheless, in short or incomplete examples of pustulose or nodose burrows preserved in hyporelief, assignment or otherwise to $N$. multiserialis can be difficult and is best assessed by including analysis of transverse or longitudinal vertical sections.

\section{Conclusions}

(1) Neonereites must be retained as a separate ichnogenus, in as much as it is an accurate, unambiguous and generally stable designation for an unmistakable and easily recognizable ichnotaxon.

(2) Contrary to the suggestion by Crimes and Crossley (1991), Neonereites multiserialis is a distinctive ichnospecies that should not be considered synonymous with $N$. biserialis.

(3) Recognition and distinction of Neonereites multiserialis from morphologically similar ichnogenera such as Granularia, Ophiomorpha, Ardelia and Edaphichnium is best undertaken by consideration of both its occurrence and general morphology but also by studying, whenever possible, vertical transverse and longitudinal sections through the structures.

Additionally, the recording and proposed synonymy of $\mathrm{Ne}$ onereites multiserialis herein:

(1) Represents the first record of $N$. multiserialis in Canada.

(2) Suggest that the known stratigraphic range is Silurian (Wenlock) to Tertiary (Eocene) (Pickerill and Harland, 1988; Pickerill and Donovan, 1991).
(3) Indicate that $N$. multiserialis has only been recorded from deep water flysch environments and therefore may well prove to be a useful palaeoenvironmental indicator.

\section{ACKNowledgements}

I wish to thank A. Gomez, R. McCulloch and D. Tabor for their help in all phases of the preparation of this manuscript. D. Cho, L.R. Fyffe and R. Wilson helped in the collection of the material and $R$. Miller provided repository numbers for the New Brunswick Museum. G. Narbonne supplied copies of the Russian papers by Fedonkin. Constructive reviews of the manuscript by H.J. Hofmann and G.L. Williams were much appreciated. Financial support was provided by a Natural Sciences and Engineering Council of Canada operating grant 0GP0003857, which is gratefully acknowledged.

Benton, M.J. 1982. Trace fossils from Lower Palaeozoic oceanfloor sediments of the Southern Uplands of Scotland. Transactions of the Royal Society of Edinburgh, 73, pp. 67-87.

Bown, T.M. and KraUs, M.J. 1983. Ichnofossils of the alluvial Willwood Formation (Lower Eocene), Bighorn Basin, northwest Wyoming, U.S.A. Palaeogeography, Palaeoclimatology, Palaeoecology, 43, pp. 95-128.

Bromley, R.G. and FREY, R.W. 1974. Redescription of the trace fossil Gyrolithes and taxonomic evaluation of Thalassinoides, Ophiomorpha and Spongeliomorpha. Bulletin of the Geological Society of Denmark, 23, pp. 311-335.

Chamberlain, C.K. 1971. Morphology and ethology of trace fossils from the Ouachita Mountains, southeast Oklahoma. Journal of Paleontology, 45, pp. 212-246.

1978. Recognition of trace fossils in cores. In Trace fossil concepts. Edited by P.B. Basan. Society of Economic Paleontologists and Mineralogists, Short Course 5, pp. 119-166.

Chamberlain, C.K. and BAer, J. 1973. Ophiomorpha and a new thallassinid burrow from the Permian of Utah. Brigham Young University, Geology Studies, 20, pp. 79-94.

Chaplin, J.R. 1980. Stratigraphy, trace fossil associations, and depositional environments in the Borden Formation (Mississippian), northeast Kentucky. Kentucky Geological Society Annual Fall Field Trip Guidebook, 114 p.

Crimes, T.P. 1987. Trace fossils and correlation of late Precambrian and early Cambrian strata. Geological Magazine, 124, pp. 97-119.

Crimes, T.P. and Crossley, J.D. 1991. A diverse ichnofauna from Silurian flysch of the Aberystwyth Grits Formation, Wales. Geological Journal, 26, pp. 27-64.

Crimes, T.P. and Germs, G.J.B. 1982. Trace fossils from the Nama Group (Precambrian-Cambrian) of southwest Africa (Namibia). Journal of Paleontology, 56, pp. 890-907.

Crimes, T.P., Goldrino, R., Homewood, P., Stuijvenbero, J. VAN, and WINKLER, W. 1981. Trace fossil assemblages of deep-sea fan deposits, Gurnigel and Schlieren flysch (Cretaceous-Eocene) Switzerland. Eclogae Geologicae Helvetiae, 74, pp. 953-995.

D'Alessandro, A. and Bromley, R.G. 1987. Meniscate trace fossils and the Muensteria - Taenidium problem. Palaeontology, 30, pp. 743-763.

De SAPPORTA, L.C.J.G. 1884. Les organismes problematiques des 
anciennes mers. G. Masson, Paris, 238 p.

Ehrenbero, K. 1944. Ergänzende Bemerkungen zu den seinerzeit aus dem Miozän von Burgschleinitz beschriebenen Gangkernen und Bauten dekapoder Krebse. Paläontologische Zeitschrift, 23, pp. 354-359.

Ekdale, A.A., Bromley, R.G., and Pemberton, S.G. 1984. Ichnology. The use of trace fossils in sedimentology and stratigraphy. Society of Economic Paleontologists and Mineralogists, Short Course 15, 317 p.

Fedonkin, M.A. 1977. Precambrian-Cambrian ichnocoenoses of the East European Platform. In Trace fossils 2. Edited by T.P. Crimes and J.C. Harper. Geological Joumal Special Issue 9. Seel House Press, Liverpool, pp. 183-194.

- 1980. Fossil traces of Precambrian metazoa. Izvestia Akademiyai Nauk SSSR, Seriya Geologicheskaya, 1, pp. 39 46 (in Russian).

1985. Paleoichnology of Vendian metazoa. In The Vendian System: historic-geological and palaeontological basis. Edited by B.S. Sokolov and M.A. Ivanovskiy. Nauka, Moscow, pp. 112-116 (in Russian).

Fillion, D. and Pickerill, R.K. 1990a. Ichnology of the Cambrian? to Lower Ordovician Bell Island and Wabana groups of eastern Newfoundland, Canada. Palaeontographica Canadiana, 7, $119 \mathrm{p}$.

1990b. Comments on "Substrate control of Lower Cambrian trace fossils from Bornholm, Denmark". Palaeogeography, Palaeoclimatology, Palaeoecology, 80, pp. 345-350.

Frey, R.W., HowARD, J.D., and PrYOR, W.A. 1978. Ophiomorpha: its morphologic, taxonomic, and environmental significance. Palaeogeography, Palaeoclimatology, Palaeoecology, 23, pp. 199-229.

GeinitZ, H.B. 1867. Die organischen Uberreste im Dachschiefer von Wurzbach bei Lobenstein. In Über ein Äquivalent der takonischen Schiefer Nordamerikas in Deutschland und dessen geologische Stellung. By H.B. Geinitz and K.T. Liebe. Nova Acta Akademie Caes. Leopold-Carol, Germany, Natur $\mathrm{Cu}$ rios, 33 (Abh. III), pp. 1-24.

Gibson, G.G. 1989. Trace fossils from Late Precambrian Carolina slate belt, south-central North Carolina. Journal of Paleontology, 63, pp. 1-10.

HAKES, W.G. 1976. Trace fossils and depositional environment of four clastic units, Upper Pennsylvanian megacyclothems, northeast Kansas. University of Kansas Paleontological Contributions, Article 63, 46 p.

Häntzschel, W. 1975. Trace fossils and problematica. In Treatise on invertebrate paleontology, part W, Miscellanea. Edited by $\mathrm{C}$. Teichert. Geological Society of America and University of Kansas Press, Boulder, Colorado and Lawrence, Kansas, pp. W1-W269.

LUNDGREN, S.A.B. 1891. Studier öfver fossilförande lösa block. Geologiska Förinengen i Stockholm, Förhandlingar, 13, pp. 111-121.

MacLeay, W.S. 1839. Note on the Annelida. In The Silurian System, Part II. Edited by R.I. Murchison. J. Murray, London, pp. 699-701.

McCann, T. and Pickerill, R.K. 1988. Flysch trace fossils from the Cretaceous Kodiak Formation of Alaska. Journal of Paleontology, 62, pp. 330-348.

NarbonNe, G.M. and AitKen, J.D. 1990. Ediacaran fossils from the Sekwi Brook area, Mackenzie Mountains, northwestern Canada. Palaeontology, 33, pp. 945-980.

Narbonne, G.M., Myrow, P., Landino, E., and Anderson,
M.M. 1987. A candidate stratotype for the PrecambrianCambrian boundary, Fortune Head, Burin Peninsula, southeastern Newfoundland. Canadian Journal of Earth Sciences, 24, pp. 1277-1293.

Pacześna, J. 1986. Upper Vendian and Lower Cambrian ichnocoenoses of Lublin region. Biuletyn Instytutu Geologicznego, 355, pp. $31-47$.

PaliJ, V.M., Posti, E., and Fedonkin, M.A. 1983. Soft-bodied Metazoa and animal trace fossils in the Vendian and Early Cambrian. In Upper Precambrian and Cambrian palaeontology of the East-European Platform. Edited by A. Urbanek and A.Y. Rozanov. Polish Academy of Sciences and the Geological Institute of the Academy of Sciences of the U.S.S.R., Publishing House Wydawnictwa Geologiczne, Warsaw, pp. 56-94.

Pickerill, R.K. 1981. Trace fossils in a Lower Palaeozoic submarine canyon sequence -the Siegas Formation of northwestern New Brunswick, Canada. Maritime Sediments and Atlantic Geology, 17, pp. 37-58.

1986. Stratigraphy, sedimentology and structural analysis of the geology of the Tobique Reserve lands with an economic assessment of its geologic resources. Unpublished report to the Department of Indian and Northern Affairs, Ottawa, Ontario, $61 \mathrm{p}$.

Pickerill, R.K. and Donovan, S.K. 1991. Observations on the ichnology of the Richmond Formation of eastern Jamaica. Journal of the Geological Society of Jamaica, 28, pp. 19-35.

Pickerill, R.K. and HaRLAND, T.L. 1988. Trace fossils from Silurian slope deposits, North Greenland. Grønlands Geologiske Undersøgelse, Rapport 137, pp. 119-133.

Pickerill, R.K., Romano, M., and Meléndez, B. 1984. Arenig trace fossils from the Salamanca area, western Spain. Geological Journal, 19, pp. 249-269.

Pomel, A. 1849. Matériaux pour servir a la flora fossile des terrains jurassiques de la France. Versammlung Deutscher Naturforscher und Aerzte, 25, pp. 332-354.

Powichrowski, L.K. 1989. Trace fossils from the Helminthoid Flysch (Upper Cretaceous-Paleocene) of the Ligurian Alps (Italy): development of deep marine ichnoassociations in fan and basin plain environments. Eclogae Geologicae Helvetiae, 82, pp. $385-411$.

Seilacher, A. 1960. Lebensspuren als Leitfossilien. Geologische Rundschau, 49, pp. 41-50.

- 1983. Upper Paleozoic trace fossils from the Gilf Kebir Abu Ras area in southwestern Egypt. Journal of African Earth Sciences, 1, pp. 21-34.

Seilacher, A. and Meischner, D. 1965. Fazies-Analyse im Paläozoikum des Oslo-Gebietes. Geologische Rundschau, 54, pp. 596-619.

St. Peter, C. 1978. Geology of head of Wapske River, map area J-B (21J/14). New Brunswick Department of Natural Resources, Mineral Resources Branch, Map Report 78-1, 24 p.

1979. Geology of Wapske-Odell River Arthurette region, New Brunswick, map areas I-13, I-14, H-14 (parts of 21J/11, $21 \mathrm{~J} / \mathrm{R}, 21 \mathrm{~J} / \mathrm{B}, 21 \mathrm{~J} / 14)$. New Brunswick Department of Natural Resources, Mineral Resources Branch, Map Report 79-2, 32 p.

Tanaka, K. 1971. Trace fossils from the Cretaceous Flysch of the Ikushumbetso Area, Hokkaido, Japan. Geological Survey of Japan, Report 242, pp. 1-31.

Weller, S. 1899. Kinderhook faunal studies I. The fauna of the vermicular sandstone at Northview, Webster County, Mis- 
souri. Transactions of the Academy of Science of St. Louis, 9. pp. 9-51.

Wilson, R.A. 1990. Geology of New Denmark-Salmon River area Victoria County, New Brunswick (parts of NTS J/13, $21 \mathrm{~J} / 14$, 210/3, 210/4). New Brunswick Department of Natural Resources, Minerals and Energy Division, Report of Investiga- tion $23,67 \mathrm{p}$.

Yano, S., Song, Z., and Liang, D. 1986. Trace fossils from Jurassic and Cretaceous flysches in Shiquanhe-Duoma region, western Tibet. In Proceedings of the Symposium on Mesozoic and Cenozoic geology. Edited by J. Huang. Geological Publishing House, Beijing, pp. 219-228. 